\title{
Protection against Nerve Toxicity by Monoclonal Antibodies to the Sodium Channel Blocker Tetrodotoxin
}

\author{
Rachel I. Huot, ${ }^{*}$ Deborah L. Armstrong, ${ }^{\ddagger}$ and Tran C. Chanh* \\ *Departments of Virology and Immunology, Southwest Foundation for Biomedical Research, San Antonio, Texas 78284; and the \\ ${ }^{\ddagger}$ Division of Life Sciences, University of Texas at San Antonio, San Antonio, Texas 78285
}

\begin{abstract}
The sodium channel blocker, tetrodotoxin (TDT), was conjugated to keyhole limpet hemocyanin (KLH) and used to immunize BALB/c mice. Anti-TDT antibodies were detected in serum by ELISA and reached stable levels 4-5 wk after the first immunization. Spleens from immunized mice were fused with NS-1 mouse myeloma cells and $\sim 9,329$ resultant hybrids were screened by ELISA for reactivity to TDT. Two stable hybrids were isolated, subcloned, and characterized. These hybrids, termed TD13a1 and TD2C5, secreted specific anti-TDT antibodies that recognized TDT but not the related sodium channel blocker, saxitoxin (STX), as determined by competition ELISA. Both antibodies were of the $\operatorname{IgG}_{1 k}$ subclass with $K_{\alpha}$ 's approaching $10^{7} \mathrm{M}^{-1}$. The inhibitory ability of these antibodies was tested by a competitive displacement assay for $\left[{ }^{3} \mathbf{H}\right] \mathrm{STX}$ on rat brain membranes. Both antibodies strongly inhibited TDT binding to membranes. A nanomole of TD2C5 was able to bind $\sim 1.8 \mathrm{nmol}$ of TDT, whereas a comparable amount of TD13a1 bound half as much. Furthermore, TD2C5 was able to protect against TDT-induced reduction of peripheral nerve action potentials in rat tibial nerve when administered in situ. These antibodies thus represent potentially useful reagents for neurobiologic research, detection of toxin contamination and diagnosis of poisoning, and may provide protection against the toxicity of TDT in vivo.
\end{abstract}

\section{Introduction}

Tetrodotoxin (TDT), ${ }^{1}$ a heterocyclic guanidinium compound, is one of the most lethal poisons known, with an $\mathrm{LD}_{50}$ of $\sim 10$ $\mu \mathrm{g} / \mathrm{kg}$ in mice (1). Death occurs through a rapidly progressive weakening of voluntary muscles, including respiratory muscles, resulting from the interruption of neuromuscular transmission in motor neurons (2) and in muscle fiber membrane (3). Responsible for $\sim 100$ deaths annually in Japan (4), TDT is found in animal species as diverse as newts and puffer fish (5). This widespread distribution of TDT across animal species

Address reprint requests to Dr Tran C. Chanh, Department of Virology and Immunology, Southwest Foundation for Biomedical Research, P. O. Box 28147, San Antonio, TX 78284.

Received for publication 31 October 1988 and in revised form 3 February 1989.

1. Abbreviations used in this paper: $\mathrm{KLH}$, keyhole limpet hemocyanin; STX, saxitoxin; TDT, tetrodotoxin.

J. Clin. Invest.

(c) The American Society for Clinical Investigation, Inc.

$0021-9738 / 89 / 06 / 1821 / 06 \$ 2.00$

Volume 83, June 1989, 1821-1826 and its apparent lack of in situ biosynthesis (6) suggested an exogenous source for this toxin, which was subsequently confirmed by the isolation of a variety of TDT-synthesizing bacteria (7).

TDT has generated considerable interest in the field of neurobiology by its ability to block sodium ion transport (8). Sodium currents can be blocked by as little as 1-10-nM concentrations of TDT in nerve and muscle (9) and the TDTbinding site is thought to lie on the external surface of membranes rather than inside the sodium channels, per se (10). A $260-\mathrm{kD}$ protein has been implicated as the TDT binding site (11).

Despite the potential public health usefulness of detecting and neutralizing the toxicity of TDT, little immunologic interest has been centered on this compound. Detection of TDT has relied heavily on mouse bioassays (12) and on chemical assays (13) that have been hampered by low sensitivity or by the presence of interfering compounds. More recently, sensitive bioreceptor assays using crude brain membranes have permitted the detection of less than a nanogram of TDT per milliliter in buffer or serum solutions (14). Although sensitive, the radioreceptor assay does not lend itself to large scale screening. The availability of specific anti-TDT antibodies would permit the development of highly sensitive immunoassays that could be used to rapidly screen for the presence of TDT. To the best of our knowledge, no anti-TDT MAb have been reported. Because of the dearth of antibodies to this toxin, we sought to generate MAb that were specific for TDT. We now describe two stable, specific MAb that demonstrate an inhibitory effect against TDT in vitro and in situ.

\section{Methods}

Generation of MAb to TDT. Because of its small size, TDT (Sigma Chemical Co., St. Louis, MO) was conjugated to keyhole limpet hemocyanin (KLH; Calbiochem-Behring Corp., La Jolla, CA) via formaldehyde as the coupling agent $(15,16)$ to render it immunogenic. Briefly, $300 \mu \mathrm{g}$ of TDT in $1,000 \mu \mathrm{l}$ of $1 \mathrm{M}$ sodium acetate buffer, $\mathrm{pH}$ 7.4 , was conjugated to $80 \mu \mathrm{l}$ of $\mathrm{KLH}(53 \mathrm{mg} / \mathrm{ml})$ in the presence of 60 $\mu 1$ of $37 \%$ formaldehyde. The mixture was shaken at $37^{\circ} \mathrm{C}$ for $3 \mathrm{~d}$ and dialyzed for $24 \mathrm{~h}$ at $4^{\circ} \mathrm{C}$. After dialysis, the TDT-KLH was precipitated with $800 \mu \mathrm{l}$ of $10 \%$ aluminum potassium sulfate and $500 \mu \mathrm{l}$ of $1 \mathrm{~N}$ $\mathrm{NaOH}$ at $4^{\circ} \mathrm{C}$. The resulting precipitate was washed six times with cold PBS. Conjugates were prepared freshly for each immunization.

Female BALB/c mice (6-8 wk old) were immunized at weekly intervals with $50 \mu \mathrm{l}(50 \mu \mathrm{g})$ of TDT-KLH conjugate per mouse mixed with an equivalent volume of CFA (Difco Laboratories, Detroit, MI) intradermally for the first immunization, Freund's incomplete (intradermally) for the second, and PBS (intraperitoneally) for all subsequent injections. Sera were collected at weekly intervals. $4 \mathrm{~d}$ after a final intravenous immunization in the tail vein, the spleen was removed and the cells were fused with NS-1 myeloma (17) cells in $40 \%$ polyethylene glycol-4000 (Accurate Chemical and Scientific Corp., Westbury, NY) according to Gefter et al. (18) at a ratio of three to six 
spleen cells per myeloma cell in serum-free DME. The fused cells were cultured in 96-well microculture plates (Corning Glass, Corning, NY) at a density of $0.5-1 \times 10^{6}$ cells $/ \mathrm{ml}$ in the presence of DME-hypoxanthine-aminopterin-thymidine (HAT) selective medium (19) containing $10 \%$ fetal bovine serum (Hazelton Research Products, Inc., Lenexa, KS), $2 \mathrm{mM}$ glutamine, $1 \times$ nonessential amino acids, $1 \mathrm{mM}$ sodium pyruvate, $10 \mathrm{mM}$ Hepes, $50 \mathrm{IU} / \mathrm{ml}$ penicillin and $50 \mu \mathrm{g} / \mathrm{ml}$ streptomycin purchased from Mediatech (Washington, DC). Plates were refed with HAT medium $3 \mathrm{~d}$ later and subsequent feedings contained HT but no aminopterin.

ELISA for the detection of anti-TDT antibodies. Culture supernatants and mouse sera were screened for TDT-specific antibodies by ELISA $(15,16)$. Briefly, $700 \mu \mathrm{g}$ of TDT or saxitoxin (STX) obtained from Dr. John Hewetson (U. S. Army Medical Research and Development Command, Fort Detrick, MD) were conjugated to $6 \mathrm{mg}$ of BSA (Calbiochem-Behring Corp.) with $41 \mu \mathrm{l}$ of $37 \%$ formaldehyde and incubated for $3 \mathrm{~d}$ at $37^{\circ} \mathrm{C}$. They were then dialyzed for $3 \mathrm{~d}$ at $4^{\circ} \mathrm{C}$ against PBS. Polystyrene plates (Costar Corp., Cambridge, MA) were coated with $50 \mu \mathrm{l} /$ well of a $10 \mu \mathrm{g} / \mathrm{ml}$ solution of STX-BSA or TDT-BSA and stored at $4^{\circ} \mathrm{C}$ until needed. The plates were blocked with $200 \mu \mathrm{l}$ of $5 \%$ normal goat serum (Cone Biotech, Seguin, TX) in PBS for $1 \mathrm{~h}$ at $37^{\circ} \mathrm{C}$ followed by incubation with supernatants or dilutions of sera $(100 \mu \mathrm{l})$ for an additional hour at $37^{\circ} \mathrm{C}$. After the plates were washed three times with PBS containing 1\% Tween-20, pH 7.5, $50 \mu \mathrm{l}$ of a 1:2,500 dilution of goat anti-mouse Ig conjugated to horseradish peroxidase (Fisher Scientific, Orangeburg, NY) were then added for $1 \mathrm{~h}$ at $37^{\circ} \mathrm{C}$. The wells were again washed and were then developed with $100 \mu \mathrm{l}$ of 2,2-azino-di-3-ethyl-benzthiazoline-6-sulfonate, $0.3 \%$ in $0.1 \mathrm{M}$ citric acid buffer, pH 4.0 (ABTS; Sigma Chemical Co.) The reaction was terminated by adding $100 \mu \mathrm{l}$ of 5\% SDS in PBS and absorbance was read at $410 \mathrm{~nm}$ in a microplate reader (Dynatech Laboratories, Alexandria, VA).

Positive clones were transferred to 24-well plates (Costar Corp.) and subcloned by limiting dilution as rapidly as possible. Positive subclones were selected on the basis of antibody reactivity by ELISA and were resubcloned until the majority of the subclones were antibody positive. Aliquots of positive clones were cryopreserved in liquid nitrogen.

Antibody specificity and isotype. Because of the structural similarity between TDT and another sodium channel blocker, STX, the specificity of antibody secreted by the TD2C5 and TD13al anti-TDT positive cell lines was evaluated by concurrently testing supernatant from each cell line for cross-reactivity in a competition ELISA using TDT-BSAcoated wells. Supernatants to be tested $(100 \mu l)$ were incubated with 50 $\mu \mathrm{l}$ of the following: PBS, STX $(200 \mu \mathrm{g} / \mathrm{ml})$ or TDT $(200 \mu \mathrm{g} / \mathrm{ml})$, for $1 \mathrm{~h}$ at $37^{\circ} \mathrm{C}$ before addition to TDT-BSA coated wells. A test antibody was considered specific if TDT reduced the $O_{410} \mathrm{~nm}$ by $>75 \%$ relative to the PBS control with STX having no effect, and if the antibody demonstrated no binding reactivity in STX-BSA-coated plates.

Antibody isotype was evaluated by direct viable immunofluorescence. Hybrid cells were washed and incubated in the presence of either goat anti-mouse $\gamma_{1}, \gamma_{2 a}, \gamma_{2 b}, \gamma_{3}, \mu$ or polyvalent anti-Ig conjugated to FITC. Cells were then washed and analyzed by a FACS (Becton Dickinson, Mountain View, CA). Isotype was further confirmed by a sandwich ELISA in which purified rabbit anti-mouse $H$ and $L$ chain isotypes-specific antisera (Bio-Rad Laboratories, Richmond, CA) were employed. Briefly, microtiter plates precoated with TDTBSA were blocked for $1 \mathrm{~h}$ at $37^{\circ} \mathrm{C}$ with $5 \%$ normal goat serum. $100-\mu \mathrm{l}$ antibodies were then added and incubated for another hour at $37^{\circ} \mathrm{C}$ After washing the plate with PBS-Tween, $50 \mu$ l of the rabbit antimouse subclass-specific antisera were then introduced for $1 \mathrm{~h}$ at $37^{\circ} \mathrm{C}$. The plates were again washed and $50 \mu$ l of goat anti-rabbit Ig conjugated to horseradish peroxidase added for $1 \mathrm{~h}$ at $37^{\circ} \mathrm{C}$. The plate was again washed, developed with $\mathrm{ABTS}$, and read at $\mathrm{A}_{410 \mathrm{~nm}}$.

Determination of relative binding affinity constant. The relative binding affinity of antibody for TDT was determined by $\mathrm{IC}_{50}(20)$ competitive inhibition enzyme immunoassay. In this assay, dilutions of antibody-containing supernatants were tested by ELISA and the
$50 \%$ binding point was estimated. The dilution yielding $50 \%$ binding $(100 \mu \mathrm{l})$ was then incubated with different toxin concentrations $(50 \mu \mathrm{l}$ at $12 \mathrm{ng} / \mathrm{ml}$ to $50 \mu \mathrm{g} / \mathrm{ml}$ ) in serial twofold dilutions for $1 \mathrm{~h}$ at $37^{\circ} \mathrm{C}$ followed by ELISA. To determine the IC $_{50}$ (molar concentration of toxin giving $50 \%$ reduction in OD), the OD were converted to percent reduction of maximal $\mathrm{OD}(y)$. The $y$ values were then converted to a logit according to the following formula: logit $=\ln y / 100-y$. Logit values were plotted against molar toxin concentration on semilog paper and the $\mathrm{IC}_{50}$ was determined graphically by dropping a vertical line to the $x$-axis from the point where the straight line crossed logit $=0$. The relative affinity constant $K_{\mathrm{a}}$ is the reciprocal of the $\mathrm{IC}_{50}$.

Antibody purification. Ascites fluid was harvested from pristaneprimed mice that had been injected with $5 \times 10^{6}$ hybridoma cells each. The fluids were clarified by centrifugation $(10,000 \mathrm{~g}, 10 \mathrm{~min})$ and the presence of antibody was confirmed by ELISA. A combination of caprylic acid and saturated ammonium sulfate precipitations (21) was then used to purify both antibodies that are of the $\mathrm{IgG}_{1}$ subclass. Purity was checked electrophoretically by SDS-PAGE (22).

In vitro membrane receptor binding assay. The ability of STX and TDT to bind stoichiometrically (23) to a common receptor site was used in radioreceptor assays $(14,24)$ to demonstrate the protective abilities of anti-TDT MAb. Crude membrane receptors from the brains of female AXC/SSh rats (from the colony maintained at the Southwest Foundation for Biomedical Research) were prepared according to Strichartz (24) and their protein content determined by the Bradford method (25) using a commercially available kit (Bio-Rad Laboratories). Aliquots were stored at $-80^{\circ} \mathrm{C}$ until needed. Optimum incubation times and binding conditions of $\left[{ }^{3} \mathrm{H}\right] \mathrm{STX}$ to the brain membranes were determined according to the radioreceptor studies above $(14,24)$. Because the TDT specificity of the anti-TDT antibodies precluded their binding to $\left[{ }^{3} \mathrm{H}\right] \mathrm{STX}$ directly nor is suitable radiolabeled TDT readily available (26), a competitive displacement assay was developed to assess the TDT-binding capacity of the anti-TDT antibodies. Membranes ( $500 \mu \mathrm{g}$ protein in $25 \mu \mathrm{l}$ ) were added to microfuge tubes and incubated under saturating conditions in the presence of $\left[11-{ }^{-3} \mathrm{H}\right] \mathrm{STX}$ with a specific activity of $63 \mathrm{Ci} / \mathrm{mmol}$ (Amersham Corp., Arlington Heights, IL) at a final concentration of $6 \mathrm{nM}$. Various amounts of radioinert TDT (0.1-10 ng) were included in the presence and absence of a constant, known, concentration of antibody for $1 \mathrm{~h}$ at $4^{\circ} \mathrm{C}$ and the amount of $\left[{ }^{3} \mathrm{H}\right] \mathrm{STX}$ bound was measured. Two competition curves for $\left[{ }^{3} \mathrm{H}\right] \mathrm{STX}$ binding were thus generated, with and without anti-TDT antibody, respectively, and the amount of TDT giving $50 \%$ of $\left[{ }^{3} \mathrm{H}\right] \mathrm{STX}$ binding in the presence and absence of antibody calculated graphically on each curve. The difference between these two values represented the amount of TDT bound by antibody. Similar displacement curves were generated in the presence of radioinert STX to demonstrate the specificity of binding of anti-TDT antibodies for TDT and not STX.

In situ protection of peripheral nerve function with anti-TDT antibody. 30 male Sprague-Dawley rats (age 40-60 d) were used. Sodium pentobarbital (Nembutal) was administered intraperitoneally (60 $\mathrm{mg} / \mathrm{kg}$ body $\mathrm{wt}$ ) and the rats were placed on an isothermal heating pad. The left rear leg and hip were shaved and the leg was immobilized on a small surgical platform. A dissection was performed to expose the sciatic nerve and tibial branch entering the gastrocnemius muscle. The skin surrounding the incision was lifted and secured with hemostats to form an enclosure for bathing the nerve in warm $0.9 \% \mathrm{NaCl}$ that contained the various antibody and TDT concentrations. The solutions were applied and withdrawn using Pasteur pipettes.

Bipolar stimulating and recording electrodes manufactured from Teflon-insulated silver wire were positioned beneath the sciatic and tibial nerves, respectively. Single square-wave pulses $(0.05 \mathrm{~ms}$ duration) were used to evoke action potentials that were recorded with a differential amplifier (World Precision Instruments, New Haven, CT). The tibial nerve responses were displayed and photographed using a storage oscilloscope (Tektronix, Inc., Beaverton, OR). Response amplitude was measured as the difference between the most positive and negative deflection of the compound action potential waveform. The 
stimulus intensity (3-6 V) was adjusted to produce maximal compound action potential amplitude. Before any application of antibody or toxin the action potential amplitude was recorded every $30 \mathrm{~s}$ for a 3-min period and the average of these six responses formed the baseline data for each preparation. Experimental treatment consisted of soaking the nerve for two 5-min periods in either antibody alone (control), TDT alone, or TDT combined with antibody. When toxin and antibody treatments were carried out the antibody was added to the toxin solution $1 \mathrm{~h}$ before application. After $5 \mathrm{~min}$ of soaking the nerve the solution was then removed and the average response amplitude was determined as described above for baseline data. The same solution was then reapplied for an additional $5 \mathrm{~min}$ and withdrawn; the average response amplitude was again determined. At the end of the experiment the animal was killed by an overdose of Nembutal.

Baseline and experimental responses were compared using analysis of variance (ANOVA) with a general linear model procedure (SAS Institute, Cary, NC). Data displaying an overall significance level of $P$ $<0.05$ were further analyzed with the Newman-Keuls multiple-range test.

\section{Results}

Detection of specific $M A b$ to TDT. Sera from TDT-immunized mice frequently demonstrated antitoxin reactivity by ELISA as early as $1 \mathrm{wk}$ after the first immunization (data not shown). Anti-TDT antibody titers increased with time and reached stable levels at $\sim$ 4-5 wk and thereafter. After mice had received six or more injections with immunogen to ensure that their serum anti-TDT titers had reached maximal levels, their spleen mononuclear cells were fused with NS-1 mouse myeloma cells for the generation of hybridomas. Of the 9,329 clones tested, $337(3.6 \%)$ were positive for anti-TDT antibodies by ELISA. Of these, two highly stable clones (TD2C5 and TD13a1) were isolated. These were subcloned and resubcloned until most or all of the derivative cultures were antibody positive. The specificity of TD2C5 and TD13a1 antibodies for TDT in a TDT-BSA competition ELISA is shown in Table I. The presence of $100 \mu \mathrm{g} / \mathrm{ml}$ TDT completely inhibited the binding of both antibodies, whereas the same amount of STX or PBS had no effect. Free TDT at a concentration of 50 $\mathrm{ng} / \mathrm{ml}$ inhibited the binding of the TD2C5 and TD13a 1 MAbs by $\sim 50$ and $25 \%$, respectively. In addition, neither antibody bound to an STX-BSA-coated plate (data not shown), further confirming their specificity for TDT. The most reactive sub-

Table I. Specificity of anti-TDT MAb by TDT-BSA ELISA

\begin{tabular}{ccccc}
\hline & \multicolumn{4}{c}{ Inhibitors $(\mu \mathrm{g} / \mathrm{ml})$} \\
\cline { 2 - 5 } \cline { 3 - 4 } $\begin{array}{c}\text { Anti-TDT } \\
\text { MAb }\end{array}$ & PBS & STX (100) & 100 & 0.05 \\
\hline TD2C5 & 0.289 & $0.303(0)$ & $0.029(90)$ & $0.150(48)$ \\
TD13a1 & 0.336 & $0.307(8)$ & $0.011(92)$ & $0.251(25)$
\end{tabular}

Antibody was incubated for $1 \mathrm{~h}$ at $37^{\circ} \mathrm{C}$ in the presence of PBS, STX, or TDT at various concentrations before addition to an ELISA plate coated with $10 \mu \mathrm{g} / \mathrm{ml}$ of TDT-BSA as the solid phase. Selected inhibitor concentrations are displayed for ease of comparison. Data are the mean of duplicate $O D_{410 \mathrm{~nm}}$ determinations and the numbers in parentheses represent the percent inhibition of binding.

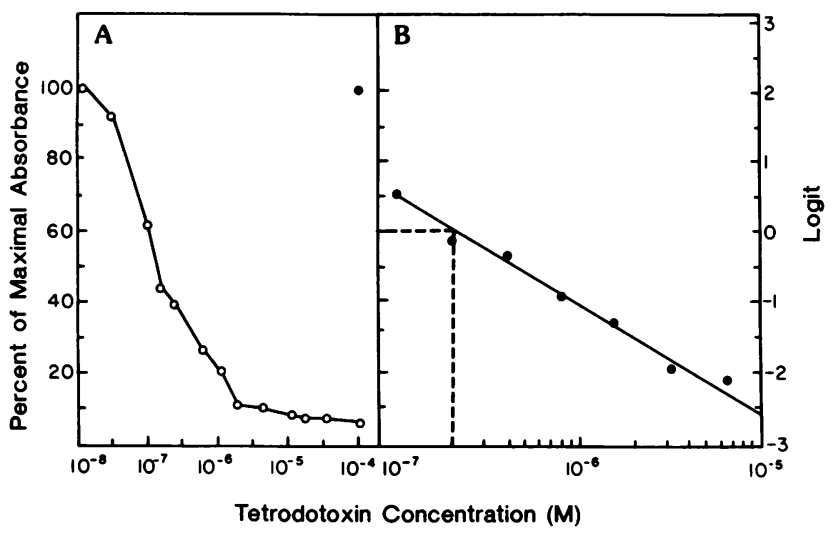

Figure 1. Inhibition of TD2C5 anti-TDT antibody binding by TDT. The MAb, TD2C5 $(A)$ was incubated in the presence or absence of STX (๑) or TDT (O) at the concentrations indicated. The $\mathrm{IC}_{50}$ determination of the data presented in $A$ is depicted in $B$ (see Methods).

clones of these hybridomas were chosen and characterized further.

Antibody isotype and affinity. The antibody isotype of the above two clones was determined and both were of the $\operatorname{IgG}_{1 k}$ subclass. By $\mathrm{IC}_{50}$ analysis, the anti-TDT MAb possessed the following $K_{\mathrm{a}}$ 's: TD2C5, $0.5 \times 10^{7} \mathrm{M}^{-1}$ and TD13a1, $0.2 \times 10^{7}$ $\mathbf{M}^{-1}$. The titration-inhibition data for one of these antibodies, TD2C5, is illustrated in Fig. $1 A$. A predetermined dilution of TD2C5 giving $\sim 50 \%$ binding in a TDT-BSA ELISA was mixed with concentrations of TDT ranging from $10^{-4}$ to $10^{-8}$ $M$. The reduction in TD2C5 binding in the presence of free TDT is shown in Fig. $1 A$. The binding of TD2C5 was inhibited by $\sim 40 \%$ by as little as a $10^{-7} \mathrm{M}$ solution of TDT, whereas a 1,000-fold higher concentration of STX had no effect, again demonstrating the specific binding of TD2C5 to TDT and not STX. The $\mathrm{IC}_{50}$ analysis of the TD2C5 antibody is displayed in Fig. $1 B$ and was generated from the data presented in Fig. $1 A$, yielding an $\mathrm{IC}_{50}$ value of $2 \times 10^{-7} \mathrm{M}$. The $\mathrm{K}_{a}$ is therefore the reciprocal of the $\mathrm{IC}_{50}$ or $0.5 \times 10^{7} \mathrm{M}^{-1}$. Similar analyses were used for TD13al (data not shown).

Inhibitory effect of anti-TDT antibodies in vitro. Using the brain receptor displacement assay, both anti-TDT antibodies demonstrated the ability to bind radioinert TDT and prevent its binding to the receptors resulting in increased binding of [ $\left.{ }^{3} \mathrm{H}\right] \mathrm{STX}$ to these receptors. TD2C5 $(1.3 \mu \mathrm{g})$ was able to displace $\sim 5 \mathrm{ng}$ of TDT at the $50 \%$ inhibition point (Fig. 2). In terms of molar capacity, $1 \mathrm{nmol}$ of TD2C5 bound $1.8 \mathrm{nmol}$ of TDT, which approached the theoretical capacity of $2 \mathrm{nmol}$ of antigen bound by $1 \mathrm{nmol}$ of an IgG antibody. The high specificity of this antibody was also manifested by the inability of even a 10 -fold higher $(13 \mu \mathrm{g})$ amount of antibody to bind STX (Fig. 2). $1 \mathrm{nmol}$ of the antibody TD13a1, by similar analysis, bound $0.87 \mathrm{nmol}$ of TDT (data not shown).

In situ protection against TDT-induced nerve toxicity by $T D 2 C 5$. The results of these experiments are summarized in Table II. The amplitudes of the action potentials generated in rat tibial nerve were recorded in the presence of $5.5 \mu \mathrm{M}$ TD2C5 alone (control), in the presence of $10 \mu \mathrm{M}$ TDT alone (TDT), and in the presence of $10 \mu \mathrm{M}$ TDT plus $5.5 \mu \mathrm{M}$ TD2C5 (Exp 1), $10 \mu \mathrm{M}$ TDT plus $2.78 \mu \mathrm{M}$ TD2C5 (Exp 2) or $10 \mu \mathrm{M}$ TDT plus $0.5 \mu \mathrm{M}$ TD2C5 (Exp 3). Baseline recordings were made, before addition of any compound and effects of 


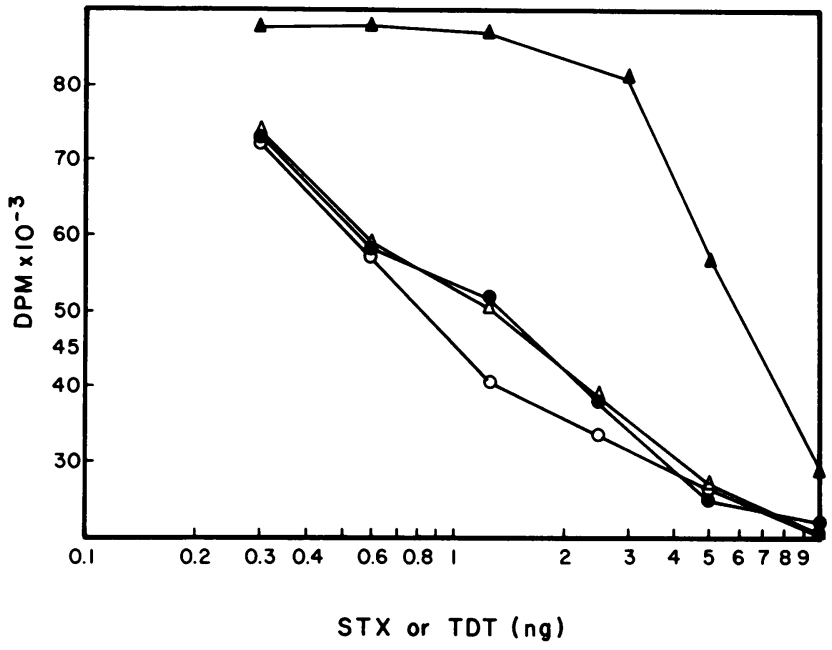

Figure 2. Competitive displacement of STX-and TDT-mediated inhibition of $\left[{ }^{3} \mathrm{H}\right] \mathrm{STX}$ binding to rat brain membranes by TD2C5. $\left[{ }^{3} \mathrm{H}\right]-$ STX binding was performed in the presence of: $(0)$ STX alone, $(\Delta)$

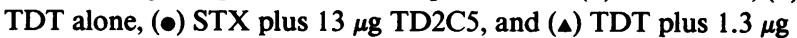
TD2C 5 for $1 \mathrm{~h}$ at $4^{\circ} \mathrm{C}$.

the test agents were measured after two 5-min exposure periods. When antibody was applied alone there was no signifcant change in response amplitude. However, application of the toxin alone reduced the compound action potential to $37 \%$ of baseline after $5 \mathrm{~min}$ and to $22 \%$ after an additional $5 \mathrm{~min}$. Addition of the two highest concentrations of TD2C5 (Exps 1 and 2, Table II) markedly counteracted the diminution in response amplitude caused by TDT, whereas the lowest dose (Exp 3) afforded little protection against TDT action. Typical effects of TDT on action potentials in the presence of $5.5 \mathrm{mM}$ TD2C5 alone (control), $10 \mathrm{mM}$ TDT alone (TDT), and 10 $\mathrm{mM}$ TDT plus $5.5 \mathrm{mM}$ TD2C5 (TD2C5) are depicted in Fig. 3 . Addition of TD2C5 completely prevented the toxic effect of TDT on action potentials. The small differences in waveform shape shown in the three baseline traces were due to slight

Table II. Comparison of Baseline and Experimental Nerve Response Amplitudes (in Millivolts) in the Presence or Absence of TDT and/or TD2C5 Anti-TDT Antibody

\begin{tabular}{ccll}
\hline Treatment $(n=6)$ & Baseline & \multicolumn{1}{c}{$5 \mathrm{~min}$} & \multicolumn{1}{c}{$10 \mathrm{~min}$} \\
\hline Control & $1.29 \pm 0.23$ & $1.20 \pm 0.25$ & $1.10 \pm 0.18$ \\
TDT & $1.31 \pm 0.23$ & $0.49 \pm 0.12^{*}$ & $0.29 \pm 0.07^{*}$ \\
Exp 1 & $1.07 \pm 0.08$ & $0.96 \pm 0.13$ & $0.85 \pm 0.08$ \\
Exp 2 & $1.27 \pm 0.10$ & $1.06 \pm 0.13$ & $0.79 \pm 0.20$ \\
Exp 3 & $1.26 \pm 0.08$ & $0.69 \pm 0.13^{*}$ & $0.40 \pm 0.09^{*}$ \\
\hline
\end{tabular}

* Significantly different from baseline or control response, $P<0.05$ (Newman-Kuels analysis).

Experimental treatment consisted of soaking exposed rat tibial nerve for $5 \mathrm{~min}$ in $5.55 \mu \mathrm{M}$ TD2C5 alone (control), $10 \mu \mathrm{M}$ TDT alone (TDT), $10 \mu \mathrm{M}$ TDT plus $5.55 \mu \mathrm{M}$ TD2C5 (Exp 1), $10 \mu \mathrm{M}$ TDT plus $2.78 \mu \mathrm{M}$ TD2C5 (Exp 2) or $10 \mu \mathrm{M}$ TDT plus $0.55 \mu \mathrm{M}$ TD2C5 (Exp 3). Baseline recordings were recorded every $30 \mathrm{~s}$ for a 3-min period before addition of any compound. Antibody and toxin were mixed together $1 \mathrm{~h}$ before adding to the nerve. Experimental measurements were performed at 5 and 10 min after addition of TDT and/or TD2C5.

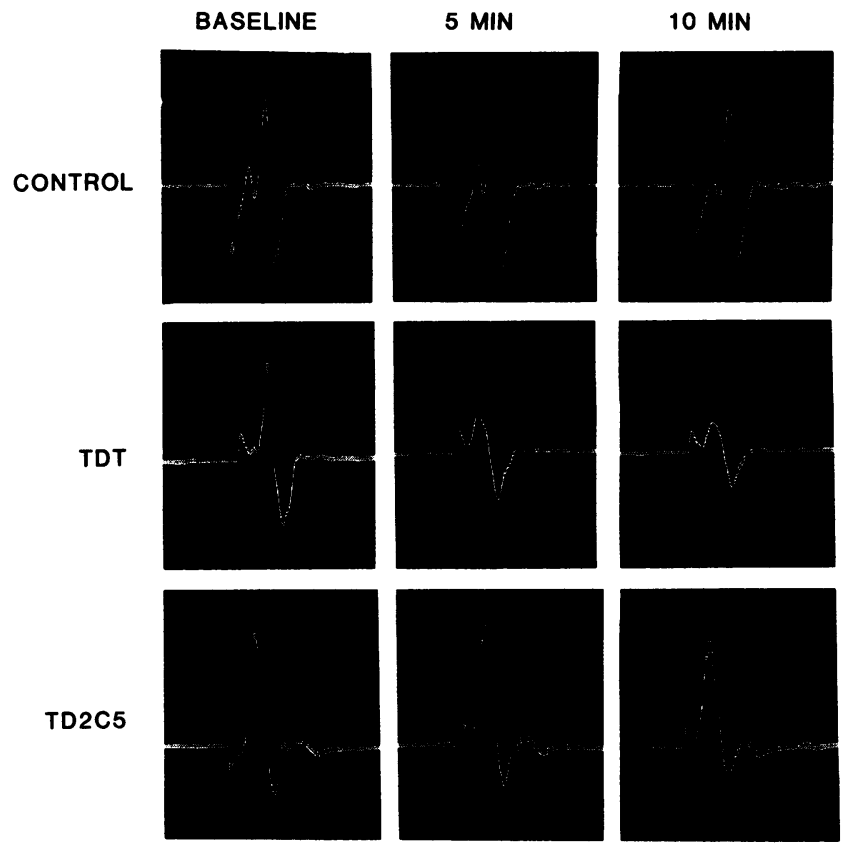

Figure 3. Comparison of tibial nerve action potentials in the presence or absence of TD2C5 antibody. Baseline recordings were made before the addition of antibody or TDT. Measurements were again performed 5 and $10 \mathrm{~min}$ after addition of $5.5 \mu \mathrm{M}$ TD2C5 alone (control), $10 \mu \mathrm{M}$ TDT alone (TDT), or $10 \mu \mathrm{M}$ TDT plus $5.5 \mu \mathrm{M}$ TD2C5 (TD2C5).

variations in electrode placement that normally occur from one recording preparation to another and do not reflect any significant difference in the nerve response.

\section{Discussion}

In this paper, we have described two anti-TDT MAb of high specificity for TDT, which to our knowledge represent the first reported MAb to TDT. Production of these MAb is highly stable, as evidenced by their continuous elaboration for over a year in culture. These MAb were generated from mice immunized with TDT-KLH conjugate in a manner as previously described for STX-KLH (27). This TDT conjugate was highly immunogenic and stimulated the production of anti-TDT antibodies in serum as early as $1 \mathrm{wk}$ after the first immunization. Spleens from all immunized mice were successfully fused with murine myeloma cells so that all fusions yielded anti-TDT positive hybridomas. The overall percentage of positive hybrids in our experiments compared favorably with those obtained (3.6\%) with the STX-KLH fusions (27).

Further testing of these positive hybrids yielded only two stable antibodies specific for TDT. These hybrids produced highly specific MAb, TD13a.1 and TD2C5, which did not cross-react with the closely related toxin, STX, even when the toxin was present at a final concentration of $100 \mu \mathrm{g} / \mathrm{ml}$. TDT, on the other hand, was easily detectable at a 1,000-fold lower concentration by either antibody. These MAb were both of the $\mathrm{IgG}_{1 k}$ subclass and possessed high affinities for TDT, with the TD2C5 MAb having the higher affinity. The differences in affinity were apparent in the $\left[{ }^{3} \mathrm{H}\right] \mathrm{STX}$ radioreceptor displacement assay, in which $1 \mathrm{nmol}$ of TD2C5 bound nearly $2 \mathrm{nmol}$ 
of TDT, whereas TD13a.1 was only able to bind $0.87 \mathrm{nmol}$. Both antibodies thus had sufficient affinity to compete for TDT binding against STX receptors on brain membranes with a $K_{\mathrm{a}} \sim 100$-fold greater than either antibody (14). The specificity for TDT and not STX of the TD2C5 MAb was also evident in the $\left[{ }^{3} \mathrm{H}\right] \mathrm{STX}$ displacement assay. Concentrations of TD2C5 10-fold higher than those used to bind TDT had no significant effect on STX displacement of $\left[{ }^{3} \mathrm{H}\right] \mathrm{STX}$ binding. This specificity of TD2C5 might prove useful in neurobiologic studies to elucidate and differentiate the binding site of TDT from STX on nerve or muscle.

The protective ability of the TD2C5 MAb was further demonstrated by its ability to inhibit TDT-induced toxicity in rat tibial nerve. TD2C5 prevented the diminution in action potential caused by a twofold greater molar concentration of TDT that correlated with the antibody-binding capacity for TDT observed in the radioreceptor assay. Although further documentation would be needed, the observations above suggest that the radioreceptor assay may serve as a screen for predicting the in situ protective effects of particular MAbs. The TD13a.1 MAb was not tested on rat nerve but based on its strong performance in the receptor assay, it is reasonable to speculate that it, too, would protect against TDT toxicity in situ.

The capacity of these MAb to interfere with TDT binding in vitro and of TD2C5 to inhibit TDT-induced toxicity in situ would strongly support the possibility that these MAb would protect against the lethal effects of TDT in vivo. In addition, the strong affinity of both MAbs for TDT might allow these MAb to be ideal vaccine candidates (28). They could be used to generate specific antiidiotypic reagents as potential vaccines for induction of a protective immune response against TDT as has been demonstrated in other systems (29). Such an antiidiotypic vaccine would obviate the potentially toxic nature of TDT conjugates as immunogens. The same conjugation methods used in this study, have tended to be unstable when used for other toxins, resulting in their potential release (30).

A further use for these antibodies could be for public health testing for the presence of contaminating TDT in seafood. They could also serve to screen patients suspected of TDT intoxication and aid in the diagnosis of poisoning.

\section{Acknowledgments}

The authors wish to thank Jacqueline Adrienne Alvarez for her excellent technical assistance.

This work was supported by contract no. DAMD17-87-C-7005 from the U. S. Army Medical Research and Development Command, Fort Detrick, MD.

\section{References}

1. Bower, D. J., R. J. Hart, P. A. Matthews, and M. E. H. Howden. 1981. Nonprotein neurotoxins. Clin. Toxicol. 18:813-863.

2. Cheymol, J., F. Bourillet, and Y. Ogura. 1962. Action de quelques paralysants neuromusculaire sur la liberation de l'acetylcholine au niveau des terminaisons nerveuses mortices. Arch. Int. Pharmaco dyn. 139:187-197.

3. Narahashi, T., T. Deguchi, N. Urakawa, and Y. Ohkubo. 1960. Stabilization and rectification of muscle fiber membrane by tetrodotoxin. Am. J. Physiol. 198:934-938.
4. Kao, C. Y. 1966. Tetrodotoxin, saxitoxin and their significance in the study of excitation phenomena. Pharmacol. Rev. 18:997-1049.

5. Mosher, H., and F. A. Fuhrman. 1984. Occurrence and origin of tetrodotoxin. In Seafood Toxins. American Chemical Society Symposium Series. Vol. 262. E. P. Ragelis, editor. American Chemical Society, Washington, DC. 332-344.

6. Shimizu, Y., and M. Kobayashi. 1983. Apparent lack of tetrodotoxin biosynthesis in captured Taricha torosa and Taricha granulosa. Chem. Pharm. Bull. (Tokyo). 31:3625-3631.

7. Yotsu, M., T. Yamazaki, Y. Meguro, A. Endo, M. Murata, H. Naoki, and T. Yasumoto. 1987. Production of tetrodotoxin and its derivatives by Pseudomonas sp. isolated from the skin of a pufferfish. Toxicon. 25:225-228.

8. Evans, M. H. 1972. Tetrodotoxin, saxitoxin, and related substances: their applications in neurobiology. Int. Rev. Neurobiol. 15:83-166.

9. Colquhoun, D., R. Henderson, and J. M. Ritchie. 1972. The binding of labeled tetrodotoxin to non-myelineated nerve fibers. $J$. Physiol. (Lond.). 227:95-126.

10. Kao, C. Y. 1986. Structure-activity relations of tetrodotoxin, saxitoxin, and analogues. Ann. NY. Acad. Sci. 479:52-67.

11. Duch, D. S., and S. R. Levinson. 1987. Neurotoxin-modulated uptake of sodium by highly purified preparations of the Electroplax tetrodotoxin-binding glycopeptide reconstituted into lipid vesicles. $J$. Membr. Biol. 98:43-55.

12. Horsburgh, D. B., E. L. Tatum, and V. E. Hall. 1940. Chemical and physiological actions of Triturus embryonic toxin. J. Pharmacol. Exp. Thera. 68:284-291.

13. Onoue, Y., T. Noguchi, Y. Nagashima, K. Hashimoto, M. Ito, and $\mathrm{K}$. Tsukuda. 1983. Separation of tetrodotoxin and paralytic shellfish poisons by high-performance liquid chromatography with a fluorometric detection using o-phthalaldehyde. J. Chromatogr. 257:373379.

14. Davio, S. R., and P. A. Fontelo. 1984. A competitive displacement assay to detect saxitoxin and tetrodotoxin. Anal. Biochem. 141:199-204.

15. Chu, F. S., and T. S. L. Fan. 1985. Indirect enzyme-linked immunosorbent assay for saxitoxin in shellfish. J. Assoc. Off. Anal. Chem. 68:13-16.

16. Johnson, H. M., P. A. Frey, R. Angelotti, J. E. Campbell, and K. H. Lewis. 1964. Haptenic properties of paralytic shellfish poison conjugated to proteins by formaldehyde treatment. Proc. Soc. Exp. Biol. Med. 177:425-430.

17. Kohler, G., and C. Milstein. 1976. Derivation of specific antibody-producing tissue culture and tumor lines by cell fusion. Eur. $J$. Immunol. 6:511-519.

18. Gefter, M. L., D. H. Margulies, and M. D. Scharff. 1977. A simple method for polyethylene glycol-promoted hybridization of mouse myeloma cells. Somatic Cell Genet. 3:231-236.

19. Littlefield, J. W. 1964. Selection of hybrids from matings of fibroblasts in vitro and their presumed recombinants. Science (Wash. DC). 145:709-710.

20. Zettner, A. 1973. Principles of competitive binding assays (saturation analyses). I. Equilibrium techniques. Clin. Chem. 19:699-705.

21. Reik, L. M., S. L. Maines, D. E. Ryan, M. Levin, S. Bandiera, and P. E. Thomas. 1987. A simple non-chromatographic purification procedure for monoclonal antibodies. Isolation of monoclonal antibodies against cytochrome P450 isozymes. J. Immunol. Methods. 100:123-130.

22. Laemmli, U. K. 1970. Cleavage of structural proteins during the assembly of the head of bacteriophage T4. Nature (Lond.). 227:680-685.

23. Narahashi, T., H. G. Haas, and E. F. Therrien. 1967. Saxitoxin and tetrodotoxin: comparison of nerve blocking mechanism. Science (Wash. DC). 157:1441-1442.

24. Strichartz, G. 1982. Structure of the saxitoxin binding site at 
sodium channels in nerve membranes. Exchange of tritium from bound toxin molecules. Mol. Pharmacol. 21:343-350.

25. Bradford, M. 1976. A rapid and sensitive method for the quantitation of microgram quantities of proteins using the principle of protein-dye binding. Anal. Biochem. 72:248-254.

26. Mosher, H. S. 1986. The chemistry of tetrodotoxin. Ann. NY. Acad. Sci. 479:32-43.

27. Davio, S. R., J. F. Hewetson, and J. E. Beheler. 1985. Progress toward development of monoclonal antibodies to saxitoxin- antigen preparation and antibody detection. In Toxic Dinoflagellates. Proceedings of the International Conference of Toxic Dynoflagellate. 3rd ed. St. Andrews, New Brunswick, Canada. D. M. Anderson, A. W. White, and D. G. Baden, editors. Elsevier Science Publishing Co., New York. 343-348.

28. Steward, M. W., and J. Steensgaard. 1983. Antibody Affinity: Thermodynamic Aspects and Biological Significance. CRC Press, Boca Raton, FL.

29. Gaulton, G. N., and M. I. Greene. 1986. Idiotypic mimicry of biological receptors. Annu. Rev. Immunol. 4:253-280.

30. Hunter, K. W., Jr., A. A. Brimfield, M. Miller, F. D. Finkelman, and S. F. Chu. 1985. Preparation and characterization of monoclonal antibodies to the trichothecene mycotoxin T-2. Appl. Environ. Microbiol. 49:168-172. 